\title{
Problems and prospects of import substitution in Russia: methodological approaches
}

\author{
Natalia Bozo, Mikhail Maslov, Marina Tsoy*, Vladislav Shchekoldin, and Sergey Petrov \\ Novosibirsk State Technical University, Karl Marks St., 20, 630073 Novosibirsk, Russia
}

\begin{abstract}
At present, the role of Russia in the world economy is mainly associated with the supply of various raw materials to world markets, the share of which in the volume of Russian exports is more than $80 \%$. At the same time, there is a rather significant processing sector of the economy in Russia. Since inertial development is aimed at simplifying the nature of the Russian economy and consolidating its raw material orientation, the development of manufacturing industries, at least at first, should be associated with protectionist measures and an active role of the state. The paper examines the existing approaches to the study of the problem of combining the principle of free trade and protectionist measures proposed by Russian and foreign authors and describes the methodological aspects of assessing the current state and prospects of implementing the import substitution policy in Russia.
\end{abstract}

\section{Introduction}

The scientific significance of the problem is caused by the contradiction between the participation of various countries in the international division of labor based on their inherent absolute and comparative advantages, on the one hand, and the need to change the existing structure of economic and industrial sectors within the framework of the industrial policy pursued in these countries, on the other hand. For Russia, this problem is undoubtedly relevant in the context of the need to diversify the Russian economy, develop high-tech industries and intensify the import substitution policy.

The aim is to develop a comprehensive system of criteria for the feasibility of developing specific import-substituting types of economic activity in the current conditions of the development of the Russian economy, considering the interests of producers and consumers of the relevant types of products, as well as society as a whole.

If feasible, modeling the processes of import substitution and assessing the values of quantitative parameters of the impact of the level of protectionist measures (duties, quotas, subsidies, etc.) on the level of competition of domestic products with imported goods to characterize the necessary and sufficient level of competition, considering both positive and negative consequences of the applied restrictions.

In world science, the main competing areas of scientific thought are free trade and protectionism, the criteria for the applicability of which are considered in many modern

\footnotetext{
${ }^{*}$ Corresponding author: mtsoi@mail.ru
} 
works. These include the works of P. Krugman [1, 2], W. Poole [3], I. Yamazavu [4], D.P. Feigelbaum and A.K. Handelwahl [5], R. Reid [6] and others.

In Russia, the problem of the development of import-substituting types of economic activity has been studied throughout the post-Soviet period in the works of A. Aganbegyan [7], O. Romanova [8], A. Makarov [9] in the dissertations of E. Nazarchuk [10], D. Zaitseva [11], L. Ismagilova [12] and others.

At the same time, at the level of microeconomics, the impact of the state "Import Substitution Program" [13] on the process of import substitution is studied little and mostly unsystematically. This is because in each specific region there is a specificity both in matters of doing business and in consumer behavior, who have different purchasing abilities and differ in their established preferences regarding domestic and foreign products. Therefore, it is of interest to study this issue at the regional level for different types of products and different types of buyers.

The train of the centuries-old state policy pursued on the territory of the Russian Federation is export-oriented and raw-material in nature, which is partly an inhibiting factor in the implementation of the Import Substitution Program, while studies indicate the need to diversify the Russian economy towards an innovative path of development.

\section{Materials and methods}

Within the framework of the research topic, it is planned to use a wide range of methods for collecting and analyzing economic information, as well as methods of expert analysis, mathematical and economic modeling, and forecasting.

At the first stage, it is planned to conduct a review of scientific approaches to the study of the problem of combining various degrees of the principle of free trade and protectionism, as well as to study existing methods and approaches aimed at assessing the effectiveness of the import substitution process; analysis of their applicability in the context of modern economic conditions in Russia, as well as expert forecasting based on the Hood and Lawley model for internal indicators of the effectiveness of import substitution programs.

It is also planned to conduct an expert analysis to identify performance indicators - the formation of a pool of experts, specialists in specialized fields; identification of indicators and factors that have a significant impact on the efficiency of the import substitution process; involvement of expert analysis methods to identify performance indicators; analysis of the selected indicators for their independence, homogeneity, relevance, representativeness and completeness to ensure the quality of research in the field of import substitution; identification of groups of interchangeable factors at the macro and micro levels, comparison of the identified groups of factors.

Based on the results obtained as a result of the review and expert analysis, the choice of indicators and criteria for assessing the effectiveness of the program is assumed, as well as the formation of sets of indicators and criteria that are relevant from the point of view of assessing the effectiveness of the import substitution program at the micro and macro levels.

When analyzing the current results of import substitution at the macro level and in the regions of the Russian Federation, a statistical database will be formed on the actual indicators of domestic and foreign trade economic activity, starting from 2011; comparison of actual values and planned values of indicators considered as target indicators of the import substitution process. The influence of the sectoral specialization of regions on the consequences of import substitution programs will be assessed using a cluster analysis of the regions of the Russian Federation by sectoral specialization; testing the hypothesis of a 
link between the industry specialization of regions and the effectiveness of the implementation of import substitution programs for different types of products.

The impact of general economic factors on the effectiveness of import substitution programs (the relationship with the devaluation of the ruble, the level of inflation, competition, etc.) is supposed to be assessed through the construction of a multifactor model describing the influence of such indicators as the level of income of the population, the exchange rate, the amount of capital investments, the level of customs protection of the domestic market. etc. on the consequences of using import substitution programs.

The analysis of the results of import substitution of goods in the $\mathrm{B} 2 \mathrm{~B}$ and $\mathrm{B} 2 \mathrm{C}$ markets will be carried out in three stages:

1. Analysis of the situation with import substitution in various segments of the economy in the B2B markets - identifying sectors of the economy in which the problem of import substitution at the regional level is especially acute; the influence of internal factors on the effectiveness of import substitution programs.

2. Comparative analysis of the consumption of imported goods during the five years of the program implementation in the B2B market - the study of ways to solve the problems of import substitution by decision-makers using the in-depth interview method (for different sectors of the B2B market).

3. Analysis of the problem of import substitution for the B2C market and identification of internal factors that determine consumer preferences - generalization and analysis of the results of research on the perception of domestic and global brands by underage consumers; research of adult consumers for import substitution in various categories of products; research of families as consumers in the context of the problem of import substitution; identification of factors influencing consumer preference for domestic products.

Finally, based on the results of the studies carried out through the application of the obtained multivariate model, a forecast of the impact of import substitution programs will be built, which will make it possible to develop recommendations for government policy measures on import substitution. Based on the proposed methodology and this model, it will be possible to formulate these recommendations, taking into account possible contradictions between the development goals of the country and regions, and the interests of individual groups of economic agents. Also, recommendations will be formulated to improve interactions in the $\mathrm{B} 2 \mathrm{~B}$ and $\mathrm{B} 2 \mathrm{C}$ markets in the context of the implementation of import substitution programs.

\section{Results and discussion}

At present, the role of Russia in the world economy is mainly associated with the supply of various raw materials to world markets, the share of which in the volume of Russian exports is more than $80 \%$. The prerequisites for this are due to the fact, in the language of classical political economy, that Russia has absolute and comparative advantages in the extraction and primary processing of various raw materials - mineral, agricultural raw materials, etc. Thus, the place in the world economy dictated by Russia by the principle of the international division of labor is the supply of raw materials, as well as the transit of goods between two major centers of the world economy - the European Union and the countries of Southeast Asia. Macroeconomically, this is expressed through the increased profitability of the raw materials sectors of the economy and the associated flow of capital and investment in these sectors. At the same time, this situation presupposes large volumes of imports of consumer products.

At the same time, there is a rather significant processing sector of the economy in Russia, partly as a legacy of the Soviet Union's economy, which, however, is experiencing problems of low competitiveness with imported products. Refusal from this sector and 
focus on the production of raw materials means a sharp reduction in the volume of the Russian economy and the employed population, which cannot be entirely concentrated only in the raw materials sector. This implies the need to preserve and develop the manufacturing sector of the economy, since the path to a long-term acceleration of economic growth can lie only through the development of production of products with high added value. Since inertial development is aimed at simplifying the nature of the Russian economy and consolidating its raw material orientation, the development of manufacturing industries, at least at first, should be associated with protectionist measures and an active role of the state, which is expressed in the current state program of the Russian Federation "Development of industry and increasing its competitiveness "for the period 2013-2024, approved by the Government of the Russian Federation (hereinafter the Import Substitution Program). The urgency of the import substitution policy increased after 2014 in the context of the intensified political confrontation between Russia and a number of foreign countries, which demonstrated the danger of orienting economic development towards raw materials production, since the sanctions imposed by a number of countries lead to restrictions on the supply of a number of products and technologies to Russia, which are often difficult to replace.

A preliminary review of the existing basic approaches to the study of the problem of combining the principle of free trade and protectionist measures proposed by Russian and foreign authors indicates a certain incompleteness of the approach to the issue of import substitution. In our opinion, the discrepancy between the planned and actual indicators based on the results of the first stage of the implementation of the Import Substitution Program should be studied comprehensively: from the standpoint of the macro and micro levels, both in the industry and in the regional context, without ignoring the conflict of interests between individual groups of consumers, producers, and public interests in the whole.

A qualitative analysis of the Import Substitution Program is not possible without a review of methods for assessing the effectiveness of the import substitution process and an analysis of their applicability in the context of modern economic conditions in Russia. The study of the state of the import substitution process in the Russian Federation is planned to be organized based on methods of expert analysis of the opinions of specialized specialists and experts from regional and industry markets. To concretize the information received, it is necessary to identify indicators and factors that have a significant impact on the efficiency of the import substitution process; as well as a group of interchangeable factors at the macro and micro levels, to compare the identified groups of factors.

To assess the interim results of the Import Substitution Program as of 2019, it is necessary to form a statistical database on the actual indicators of domestic and foreign economic activity, starting from 2008; comparison of the actual values of the indicators taken into account as target indicators of the Import Substitution Program in the periods before and after the start of its operation; comparison of planned and actual values of indicators taken into account as target indicators of the Import Substitution Program throughout the entire period of its implementation.

Assessment of intermediate results will allow clustering the regions of the Russian Federation by industry specialization and identify the presence or absence of a connection between the industry specialization of regions and the effectiveness of the implementation of subprograms within the framework of the Import Substitution Program for various types of products.

From the point of view of studying regional markets, it is of significant interest to identify sectors of the economy in which the problem of import substitution is especially acute to determine the influence of certain internal factors on the effectiveness of import substitution programs in specific regions of the Russian Federation. For this, it is proposed 
to study the ways of solving the problems of import substitution by decision-makers using the method of in-depth interviews on various industry markets.

Regarding the consumer market, characterized by the complexity and contradictory behavior of consumers, it is necessary to use specialized methods to analyze, in particular, different groups of consumers, such as adult and underage consumers, as well as take into account the behavior of households as consumers.

Evaluation and accounting of internal and external factors affecting the effectiveness of import substitution programs will make it possible to develop econometric models describing the process of import substitution and its consequences. An important result will be the assessment of the values of quantitative characteristics of a sufficient level of import substitution based on the results of regional clustering.

\section{Conclusions}

Thus, the main results that are expected to be achieved based on the results of the implementation of the proposed methods will be:

- The identification of factors and formulation of criteria for the effectiveness of import substitution of goods at the macro and micro levels.

- The development of a methodology for accounting and processing of a system of criteria assessment of consumer preferences regarding domestic and foreign goods.

- The typology of regions, markets, and consumers according to the level of policy susceptibility within the framework of the import substitution program.

- The development of multivariate models for calculating the values of quantitative characteristics of the necessary and sufficient level of import substitution based on the results of regions clustering.

- The development of recommendations for measures of state policy of import substitution based on the proposed methodology and the postulated model.

\section{References}

1. P. Krugman, American Economic Review, Papers and Proceedings, 83(3), 23 (1993)

2. P. Krugman, Peddling Prosperity: Economic Sense and Nonsense in the Age of Diminished Expectations (1994)

3. William Poole, Federal Reserve Bank of St. Louis Review (2004)

4. Ippei Yamazawa, Restructuring the Japanese Economy: Policies and Performance in Global Protectionism, 55 (1991)

5. Pablo D. Fajgelbaum, The Quarterly Journal of Economics, 131(3), 1113 (2016)

6. Robert Read, World Economy, 28 (8), 1119 (2005)

7. A. Aganbegyan, ECO, 6, 7 (2012)

8. O. Romanova, Modern Competition, 3, 32 (2008)

9. A. Makarov, Innovations, 5, 90 (2011)

10. E. Nazarchuk, Theoretical and Methodological Foundations of Effective Import Substitution at Russian Industrial Enterprises (2007)

11. D. Zaitsev, Organization of production of import-substituting products as a direction of economic development of the region (2002)

12. L. Ismagilova, Development of export-oriented and import-substituting industries as a factor of regional integration into the system of world economic relations (2004) 
13. The state program "Development of industry and increasing its competitiveness" was approved by the Decree of the Government of the Russian Federation of April 15, 2014 No. 328 